Akreditasi KEMENRISTEKDIKTI, Nomor: 148/M/KPT/2020
hettp: / /jurnal.stkippersada.ac.id/jurnal/index.php/VOX

\title{
PENINGKATAN HASIL BELAJAR IPA DENGAN MEDIA MIND MAPPING DIGITAL DI SEKOLAH DASAR
}

\author{
Cucu Ismaela ${ }^{1}, \&$ Sulistyani Puteri Ramadhani ${ }^{2}$ \\ ${ }^{1,2}$ Fakultas Keguruan dan Ilmu Pendidikan, Universitas Trilogi \\ Email: isma.refriawan@gmail.com ${ }^{1}$, sulistyani@trilogi.ac.id
}

\section{INFO ARTIKEL}

Riwayat Artikel:

Menerima : 27 Agustus 2021

Revisi : 09 September 2021

Diterima : 13 September 2021

\section{Kata Kunci:}

Hasil Belajar, IPA, Mind

Mapping Digital

\section{Keywords: \\ Learning Outcomes, Science, Mind Mapping Digital}

\section{Korespondensi:}

Cucu Ismaela

Fakultas Keguruan dan Ilmu

Pendidikan, Universitas Trilogi

Email: isma.refriawan@gmail.com

\begin{abstract}
ABSTRAK
Penelitian ini bertujuan untuk meningkatkan hasil belajar peserta didik kelas IVB SDN Pengadegan 07 Jakarta Selatan pada mata pelajaran IPA materi sumber energi dengan menggunakan media mind mapping digital yang menggunakan pendekatan Penelitian Tindakan Kelas (PTK) dengan model Kemmis and McTaggart. Berdasarkan data yang telah diperoleh melalui metode observasi, wawancara dan hasil belajar yang dilakukan oleh peneliti serta berkolaborasi dengan wali kelas IVB menunjukkan bahwa pada pra-siklus terdapat rendahnya hasil belajar peserta didik dengan $50 \%$ dari 28 peserta didik belum tuntas KKM pada mata pelajaran IPA materi sumber energi di kelas IVB SDN Pengadegan 07 Jakarta selatan yang berjumlah 28 peserta didik terdiri dari 16 orang peserta didik laki-laki dan 12 orang peserta didik perempuan, pada siklus I diperoleh hasil ketuntasan belajar yang dinilai dari kognitif terdapat presentase ketuntasan belajar klasikal adalah sebesar $71 \%$ dari 28 peserta didik dengan nilai rata-rata klasikalnya 80,4. Kemudian pada siklus II diperoleh presentase ketuntasan belajar klasikal adalah sebesar $100 \%$ dengan nilai rata-rata klasikal sebesar 88. Hal ini menunjukkan adanya peningkatan presentase ketuntasan klasikal sebesar 29\% dan peningkatan nilai rata-rata klasikalnya mencapai 7,6. Hasil penelitian ini menunjukkan bahwa penggunaan media mind mapping digital mampu meningkatkan hasil belajar peserta didik di kelas IVB SDN Pengadegan 07 Jakarta Selatan pada mata pelajaran IPA materi sumber energi.
\end{abstract}

\section{ABSTRACT}

This study aims to improve the learning outcomes of class IVB students at SDN Pengadegan 07 South Jakarta in the science subject matter of energy resources by using digital mind mapping media using the Class Action Research (CAR) approach with the Kemmis and McTaggart model. Based on the data that has been obtained through the method of observation, interviews and learning outcomes conducted by researchers as well as collaborating with the IVB class homeroom teacher, it shows that in the pre-cycle there are low student learning outcomes with $50 \%$ of the 28 students not completing the KKM in science subjects. source of energy in class IVB SDN Pengadegan 07 South Jakarta, totaling 28 students consisting of 16 male students and 12 female students, in the first cycle the results of learning mastery were obtained which were assessed from the cognitive, there was a percentage of classical learning completeness was $71 \%$ of 28 students with a classical average score of 80.4. Then in the second cycle, the percentage of classical mastery learning is $100 \%$ with an average classical value of 88 . This indicates an increase in the percentage of classical mastery by $29 \%$ and an increase in the classical average value reaching 7.6. The results of this study indicate that the use of digital mind mapping media is able to improve the learning outcomes of students in class IVB at SDN Pengadegan 07 South Jakarta in science subjects for energy sources. 


\section{PENDAHULUAN}

Pendidikan ialah cara yang digunakan dalam membuat seseorang menjadi cerdas, sehingga mampu meraih harkat dan martabatnya serta cita-cita seseorang (Rizkyani $\&$ Amelia, 2020). Pendidikan hal yang sangat penting, juga merupakan hak utama yang mesti didapatkan oleh manusia ketika ia dilahirkan. Berdasarkan Undang-Undang Nomor 20 Tahun 2003 yang sudah ditetapkan maka tujuan pendidikan itu merupakan sebuah fungsi untuk menumbuhkan potensi serta membentuk sifat agar bisa melatih kemampuan siswa agar membentuk manusia yang bertakwa serta beriman pada Tuhan Yang Maha Esa, berilmu, memiliki akhlak yang baik, inovatif, cakap dan mampu menjadi warga Negara yang bertanggung jawab (Variani \& Agung, 2020).

Kondisi saat ini, dunia tengah dilanda pandemik covid-19 maka semua aktivitas diluar harus dibatasi, salah satunya yaitu pembelajaran dilakukan dengan tatap maya secara daring (dalam jaringan). Pendidikan sekolah kini harus belajar secara jarak jauh menjadi pilihan utama pemerintah dalam menekan angka penyebaran covid-19. Pembelajaran jarak jauh menjadi solusi utama saat ini, sehingga pendidik diharapkan mampu membangkitkan aktivitas belajar peserta didik agar peserta didik merasa tidak terbebani dan tidak merasa bosan untuk mengikuti pembelajaran secara daring. Adanya pengaruh besar dari seorang pendidik dalam menentukan kreativitas pendidik dan strategi yang sesuai menjadi sebuah tantangan bagi pendidik. Kemampuan pendidik dengan keprofesionalan dan pedagogik pendidik, diharapkan dapat terus meningkatkan hasil belajar peserta didik dalam kondisi apapun, seorang pendidik dituntut untuk kreatif agar pembelajaran berjalan optimal. Berdasarkan penjelasan tersebut maka dapat peneliti simpulkan bahwa pembelajaran daring atau pembelajaran tatap muka guru harus bisa meningkatkan hasil belajar siswa termasuk pembelajaran IPA.

Kegiatan mengajar, pendidik dituntut agar membuat peserta didik dapat paham dengan materi yang dipelajari untuk suatu kehidupan. Pendidik dituntut untuk menciptakan dan membangkitkan minat belajar para peserta didik. Pembelajaran sangat dipentingkan bagi kehidupan dan terdapat pengetahuan yang berkaitan dengan kehidupan sehari-hari yaitu pembelajaran IPA. Pendapat mengenai hal tersebut dikemukakan oleh Yuliani (2020) yang mengatakan bahwa IPA ialah ilmu yang mengajarkan peserta didik untuk dapat paham mengenai suatu fenomena alam, keanekaragaman alam, dan belajar IPA manusia dapat memahami yang kemudian diajarkan secara turun temurun kepada manusia lain, hal ini agar peserta didik dapat hidup rukun dengan lingkungannya.

Berdasarkan penjelasan tersebut maka dapat peneliti simpulkan bahwa pembelajaran IPA dapat mengajarkan kepada siswa agar bisa memahami sebuah fenomena alam yang ada di sekitar siswa dan siswa dapat memahami cara menjaga serta mampu merawat alam yang ada di lingkungan siswa.

Simpulan dari pendapat tersebut bahwa manusia sebagaimana telah mendapatkan ilmu sebelumnya untuk 
kemudian diberikan ilmu tersebut kepada peserta didik untuk dapat memahami apa yang terjadi tentang fenomena-fenomena alam sekitarnya, begitu banyak keanekaragaman alam semesta ini, dan dengan belajar ilmu IPA ini diharapkan peserta didik dapat memahami bagaimana sikap yang sebenarnya dalam menjaga lingkungan sehingga diharapkan dapat menyesuaikan diri dengan lingkungan dan dengan menjaga lingkungan sekitar serta mampu merawat alam dengan baik. Salah satunya, pembelajaran seperti materi sumber energi karena pada materi ini mempelajari bagaimana bentuk dan perubahan sumber energi yang dapat mempengaruhi kehidupan sehari-hari, serta adanya sumber energi yang ada di Indonesia yang dapat dimanfaatkan. Begitu besar Indonesia memiliki bermacammacam sumber energi alternatif yang dapat digunakan untuk kehidupan sehari-hari. Peserta didik patut mengetahui bentuk dan perubahan sumber energi.

Bentuk sumber energi yang dimanfaatkan dalam kehidupan sehari-hari contohnya pembangkit lisrik tenaga air. Sumber energi pembangkit listrik tenaga air ini yang banyak dimanfaatkan oleh manusia untuk kebutuhannya dalam kehidupan sehari-hari. Pemanfaatan air perlu dibarengi dengan rasa kesadaran untuk menjaga sumber air yang ada di dunia ini, harus bijak dalam pemakaiannya tidak boros dan tidak membuang-buang air. Pembangkit listrik tenaga air ialah cara yang dipakai untuk mendapatkan suatu aliran listrik untuk masyarakat. Sumber air yang melimpah menjadikan keharusan untuk membuat pembakit listrik tenaga air di Indonesia, untuk itulah mengapa di Indonesia terdapat banyak bendungan. Bendungan ialah sebuah rangkaian suatu sistem dari pembangkit listrik. Sumber energi yang tidak dapat habis contohnya yaitu sinar matahari, yang dapat digunakan semua manusia untuk suatu kehidupan sehari-hari.

Peserta didik sekolah dasar, sebagaimana karakteristik mereka bahwa peserta didik belajar dengan yang dilihat, didengar, dan dengan benda konkret. Media yang disajikan harus dapat menarik perhatian peserta didik, juga menjadi salah satu bagian terpenting dalam aktivitas belajar peserta didik. Media yang membuat peserta didik tertarik untuk mengetahui apa yang akan dijelaskan oleh pendidik karena media yang menarik tersebut secara tidak langsung menambah minat dalam belajar. Menurut Wayan \& Ketut (2020) yang menyatakan minat ialah suatu gejala psikologis dapat menimbulkan pemusatan perhatian terhadap obyek dan dan rasa ketertarikan peserta didik. Pengertian tersebut menjelaskan bahwa media mempengaruhi proses pembelajaran peserta didik. Macammacam cara belajar peserta didik dalam menerima informasi atau mengolah pesan yang diberikan yang pertama adalah visual atau penglihatan. Mereka yang memiliki cara belajar secara visual dengan melihat serta membaca. Kedua dengan cara melalui auditori atau diterangkan dengan lisan, lebih suka mendengarkan apa yang diceritakan dan yang ketiga dengan cara melalui kinestik, yang melalui gerakan atau sentuhan (Widiana, 2016). 
Bantuan media mind mapping digital merupakan salah satu media pembelajaran aktif dan cara terunik yang disajikan dengan gambar serta menempatkan informasi yang diteruskan ke jaringan otak kemudian memperoleh informasi dari otak untuk memahami informasi secara efektif dan efisien. Mind mapping dapat menghasilkan suatu gagasan yang sudah mereka peroleh dan mencatat serta membuat tugas baru. Sehingga peserta didik dapat untuk melihat secara utuh, jelas, serta mudah agar menjadi inovatif dan kreatif. Sebuah cara dalam memetakan gagasan-gagasan sendiri, peserta didik diharapkan lebih dapat dalam memahami pelajaran (Novioleta et al., 2020). Dalam gagasan tersebut dijelaskan bahwa mind mapping dapat memudahkan peserta didik dalam mempelajari, mencatat, maupun merencanakan tugas mereka dengan mudah dan secara kreatif, dapat memetakan ide-ide pokok yang dikembangkan oleh hasil pemikiran sendiri.

Lalu kemudian ada pendapat dari Sutanto, (2013) yang mengatakan bahwa mind mapping ialah suatu sistem untuk belajar serta berpikir yang menggunakan kedua otak, penggunaan otak yang disesuaikan dengan cara kerja alaminya, serta dapat memaksimalkan potensi serta kapasitas penggunaan otak yang masih tersembunyi. Dalam kutipan tersebut media mind mapping merupakan media yang dapat mengembangkan kreativitas, pemahaman serta pemikiran peserta didik terhadap suatu informasi yang telah diperolehnya. Pada proses belajar mengajar juga pendidik diwajibkan untuk membuat, mendesain, menetapkan prosedur, strategi serta model dan metode paling cocok, agar tepat sasaran dan pembelajaran menjadi efektif. Media mind mapping akan digunakan dalam penelitian ini dan dibuat semenarik mungkin seperti yang diungkapkan Yuliani, (2020) menyatakan bahwa mind mapping mempunyai simbol, warna, dan bentuk supaya otak dapat mendapatkan sebuah informasi agar lebih mudah maka peserta didik dapat memahami materi secara mendalam dan mampu mengingat kembali secara mudah.

Berdasarkan hasil dari uraian di atas, dan hasil observasi yang telah peneliti lakukan dengan adanya kondisi pandemi covid-19 saat ini pendidik kurang menggunakan media pembelajaran yang bervariasi. Oleh karena itu hal tersebut mempengaruhi hasil belajar IPA peserta didik di SDN Pengadegan 07 pagi Jakarta Selatan. Hasil nilai ulangan harian peserta didik yang menunjukkan bahwa nilai peserta didik rata-rata dibawah KKM. Oleh sebab itu juga peneliti akan melakukan penelitian menggunakan media yang berbeda yaitu dengan media mind mapping digital. Hasil observasi wawancara di sekolah dasar yang telah di lakukan oleh peneliti, pendidik biasa menggunakan power point saat proses belajar mengajar, setelah itu peserta didik diminta mengisi soal latihan yang telah disiapkan oleh pendidik dan diberikan diakhir proses pembelajaran melalui whatsapp group (WAG) sekolah atau melalui google classroom. Pembelajaran secara tatap maya melalui zoom atau aplikasi lainnya dilakukan sangat jarang sekali, pembelajaran sering kali dilakukan hanya dengan mengirimkan materi 
dan tugas melalui aplikasi whatsapp group (WAG) sekolah. Pendidik berpendapat bahwa dengan hanya membaca materi yang diberikan pada buku LKS akan langsung dengan mudah dipahami oleh peserta didik, tanpa diberikan kembali evaluasi dari pendidik tentang pembelajaran IPA yang telah dipelajari.

Ketika pembelajaran dilakukan dengan secara tatap maya, hanya sebagian peserta didik yang aktif saat kegiatan belajar mengajar berlangsung. Sebagian peserta didik masih kurang aktif saat proses belajar, keadaan seperti ini dikarenakan peserta didik masih merasa takut untuk mengemukakan pendapatnya dan kurang percaya diri untuk mengajukan pertanyaan. Peserta didik juga mungkin bingung apa yang akan ditanyakan, ini disebabkan karena banyak materi yang harus dikuasai dalam waktu yang singkat dan waktu yang sangat terbatas. Sehingga membuat peserta didik terkadang tidak sepenuhnya menguasai materi. Setiap peserta didik pasti memiliki karakteristik yang berbeda-beda secara psikologi, dari tingkat kecerdasan, minat, bakat, serta motivasi yang ada pada masing-masing individu. Hasil wawancara dengan wali kelas IVB peserta didik senang melakukan sesuatu hal yang baru, misal membuat gambar berbentuk artikel, dibandingkan harus menulis secara langsung dan merangkum banyak materi sekaligus.

Dalam proses pembelajaran telah dilakukan oleh wali kelas dengan baik dan benar, tetapi mungkin butuh media lain untuk menarik perhatian peserta didik agar beberapa yang tadinya kurang aktif menjadi aktif. Situasi ini didukung oleh sebuah fakta yang ada di sekolah karena benar adanya bahwa pendidik lebih aktif saat kegiatan pembelajaran. Hal ini dapat mengakibatkan rendahnya hasil belajar peserta didik. Media mind mapping digital merupakan sebuah media aplikasi yang akan peneliti kembangkan pada pembelajaran IPA materi sumber energi. Sehubung dengan melihat kondisi sekarang, yang tengah dilanda pandemi covid-19 dimana banyak sekolah dasar yang akhirnya harus menggunakan bantuan smartphone atau laptop untuk melakukan proses pembelajaran setiap harinya.

Kondisi inilah, peneliti memanfaatkan situasi tersebut untuk melakukan pembelajaran dengan bantuan media mind mapping digital, yang ada di aplikasi smartphone maupun laptop yang sangat mudah dilakukan dan diaplikasikan. Peneliti akan memberikan langkah-langkah cara menggunakan media mind mapping digital kepada peserta didik sebelumnya, sesaat setelah menjelaskan materi. Hal ini sekaligus belajar bagaimana peserta didik memanfaatkan waktunya untuk hal yang lebih berguna, menuangkan dan mengasah kemampuan kreativitasnya. Tidak hanya itu mind mapping digital juga dapat mengingat informasi dengan mudah, menuangkan ide, mengumpulkan suatu informasi dengan cara yang berbeda, serta belajar dalam menggunakan teknologi digital sekaligus belajar menguasai aplikasi yang bermanfaat bagi mereka dalam membantu belajar mengajar. Sebagaimana yang telah diterangkan sebelumnya, bahwa teknologi digital saat ini menjadi solusi utama bagi pemerintah dan bagi sekolah-sekolah, serta 
membantu banyak kalangan dalam kebutuhan kehidupan sehari-hari. Media digital dianggap media yang menarik bagi peserta didik saat ini, melihat dari keadaan sekarang yang memanfaatkan belajar menggunakan teknologi digital. Zaman 4.0 ini pemanfaatan teknologi digital mengharuskan semua peserta didik untuk dapat mengoperasikan teknologi digital, bahkan jika dilihat dari pengamatan peneliti, peserta didik lebih paham menggunakan teknologi digital dibandingkan orangtuanya.

Melihat hal yang telah diuraikan di atas, maka harus ada sebuah perubahan serta pembaharuan, sebuah inovasi bagaimana cara pendidik mengajar di kelas agar dapat mencapai tujuan yang optimal. Kegiatan belajar mengajar harus dikemas secara bervariasi dengan berbagai penggunaan strategi belajar kepada peserta didik. Belajar akan lebih bermakna apabila peserta didik dapat mengalaminya secara langsung secara tatap muka ataupun tatap maya, ketika sedang mempelajari akan mengaktifkan panca indra. Berbeda dengan ketika jika hanya diberikan materi saja tanpa adanya penjelasan yang lebih dari pendidik. Peneliti akan memilih menggunakan strategi untuk dapat memberikan sebuah gambaran yang jelas, lebih mudah dipahami, berkaitan dengan materi yang telah dipelajari oleh peserta didik. Perhatian peserta didik juga akan lebih mudakh untuk diarahkan ketika mempelajari materi dengan tatap maya. Pembelajaran IPA dengan fokus bahasan yang mengacu pada materi sumber energi. Peserta didik dapat melihat berbagai sumber energi, perubahan suatu bentuk energi serta sumber energi alternatif seperti angin, air, panasnya bumi, matahari, nuklir dan bahan bakar organik yang ada pada kehidupan kita, dengan menggunakan media mind mapping digital diharapkan dapat meningkatkan hasil belajar peserta didik kelas IVB SDN Pengadegan 07 Jakarta Selatan. Dalam proses pembelajaran, peserta didik akan diajak berdiskusi bersama kemudian pendidik memperlihatkan materi yang akan dijelaskan oleh peserta didik secara lebih lanjutnya. Kemudian peserta didik dibimbing dalam pembuatan mind mapping digital yang akan dilanjutkan dengan memberikan evaluasi atau refleksi.

\section{METODE PENELITIAN}

Penelitian ini menggunakan pendekatan Penelitian Tindakan Kelas (PTK). Definisi Penelitian Tindakan Kelas atau disebut dengan PTK (Classroom Action Research) menurut (Dwitagama, 2010) penelitian tindakan kelas ialah sebuah penelitian yang dilakukan oleh pendidik dikelas sendiri dengan merencanakan, melaksanakan, dan merefleksikan tindakan secara kolaboratif serta juga partisipasi yang bertujuan untuk memperbaiki suatu kinerja pendidik, sehingga hasil belajar peserta didik dapat meningkat.

Penelitian tindakan kelas ini memakai model Kemmis and McTaggart (Dwitagama, 2010), adalah suatu pengembangan dari konsep dasar yang sebelumnya diperkenalkan oleh Kurt Lewin, namun pada model Kemmis and McTaggar ini mempunyai komponen yaitu tindakan dengan pengamatan digunakan untuk satu kesatuan ialah dua kegiatan yang tidak 
dapat terpisahkan. Penelitian tindakan kelas ini akan dilakukan praktik pembelajaran di dalam kelas secara daring dan juga dengan menganalisis tingkah laku peserta didik maupun interaksi peserta didik selama proses pembelajaran serta hasil pembelajaran yang sudah dilakukan. Kemudian terakhir dilakukan evaluasi agar mengetahui serta menentukan hasil dari tindakan. Penelitian tindakan kelas ini diharapkan pendidik melakukan kepentingan pada proses serta hasil dalam pembelajaran yang lebih optimal, efektif serta fungsional dengan menggunakan teori-teori yang sudah diadaptasi dengan adanya teori-teori yang telah dikaji.

Penelitian ini memiliki fokus utama yaitu peserta didik, dengan menggunakan materi yang telah disiapkan serta alat bantu berupa media dan hasil pembelajaran yang telah dilaksanakan. Menurut Kemmis and Mc Taggart dalam (Dwitagama, 2010) mengemukakan pendapatnya mengenai komponen penelitian tindakan kelas yaitu terdapat empat 1) perencanaan, 2) tindakan, 3) pengamatan, 4) refleksi. Hubungan dari keempat komponen itu akan menunjukkan kegiatan yang berkelanjutan secara berulangulang atau siklus. Satu siklus awal dari tahap proses perencanaan kemudian hingga tahap terakhir yaitu refleksi.

Penelitian ini dilaksanakan di kelas IVB SDN Pengadegan 07 Pagi Jakarta Selatan, subyek pada penelitian ini yaitu 28 siswa dalam satu kelas serta penelitian ini akan dilakukan secara berulang apabila siklus I belum bisa mencapai hasil yang telah ditentukan, maka peneliti akan melakukan tahap siklus II dan jika siklus II telah mencapai hasil maka dapat dikatakan tuntas atau berhasil.

Pengumpulan data pada penelitian ini yaitu peneliti menggunakan 1) observasi ialah pengumpulan data dengan cara mengadakan pengamatan terdahap kegiatan pembelajaran secara daring pada pembelajaran IPA materi sumber energi di kelas IVB SDN Pengadegan 07 pagi Jakarta Selatan sebelum serta sesudah memakai media mind mapping digital, 2) tes dipakai untuk mengetahui hasil belajar siswa sebelum dan sesudah memakai media mind mapping digital, 3) dokumentasi juga dipakai untuk mendapatkan suatu data berupa foto, data nilai siswa, RPP, 4) pengukuran hasil tes ini memiliki tujuan untuk mengetahui peningkatan hasil belajar siswa, 5) wawancara itu suatu proses agar mendapatkan keterangan dari narasumber dan membagikan kuesioner kepada wali kelas dan siswa terkait objek dalam penelitian ini.

Teknik dalam mengumpulkan data dalam bentuk kualitatif dan kuantitatif berupa data yang diperoleh berdasarkan angka untuk digunakan saat menganalisis deskriptif persentase (Sudjana, 2017). Menghitung nilai rata-rata yaitu peneliti memakai rumus sebagai berikut:

$$
M=\sum_{N}^{f x}
$$

Keterangan:

$\mathrm{M}=$ Mean (Rata-rata)

$\sum f x=$ Jumlah Nilai Seluruh Peserta Didik

$\mathrm{N}=$ Jumlah Peserta Didik 
Menghitung persentase ketuntasan belajar maka peneliti memakai rumus sebagai berikut:

$\mathrm{P}=\frac{\sum \text { Peserta didik yang tuntas belajar } \times 100 \%}{\sum \text { peserta didik }}$

\section{HASIL DAN PEMBAHASAN}

\section{A. HASIL PENELITIAN}

Penelitian Tindakan Kelas ini dilakukan pada kelas IVB SDN Pengadegan 07 Jakarta Selatan Tahun Ajaran 2020/2021. Penelitian ini juga dilaksanakan dalam 2 siklus sesuai dengan tujuan penelitian yaitu meningkatkan hasil belajar IPA khususnya materi sumber energi dengan menggunakan media mind mapping digital.

\section{Hasil Penelitian Pra-Siklus}

Data awal yang akan dipakai oleh peneliti agar mengetahui serta melihat kemampuan awal peserta didik kelas IVB SDN Pengadegan 07 Jakarta Selatan yang mengacu pada nilai hasil ulangan harian mata pelajaran IPA. Adapun hasil nilai ulangan harian siswa pada waktu sebelum diterapkannya pembelajaran dengan menggunakan media mind mapping digital bahwa peserta didik yang belum mencapai nilai KKM adalah dibawah 72 , sebagai berikut :

Tabel 1 Ketuntasan Belajar Pra-Siklus

\begin{tabular}{|c|c|c|}
\hline Nilai & $\begin{array}{c}\text { Banyaknya } \\
\text { Siswa }\end{array}$ & Keterangan \\
\hline$>72$ & 14 siswa & Tuntas \\
\hline$<72$ & 14 siswa & Tidak Tuntas \\
\hline
\end{tabular}

Nilai rata-rata hasil ulangan (pra siklus)

$=2133: 28$ siswa $=76,1$. Hasil ketuntasan belajar pada pelaksanaan tes pra siklus :

$$
\frac{14}{28} \times 100 \%=50 \% \text { dan } \frac{14}{28} \times 100 \%=50 \%
$$

Berdasarkan hasil belajar yang tertera di atas, telah diperoleh data bahwa ada 14 siswa yang telah tuntas belajar dan ada 14 siswa lainnya yang tidak tuntas. Presentase keberhasilan yang telah dicapai siswa yaitu adalah sebanyak $50 \%$ dari jumlah siswa mendapatkan nilai diatas kriteria pada ketuntasan minimal $50 \%$ dari jumlah siswa mendapatkan nilai di bawah KKM. Tidak hanya mengacu pada nilai belajar hasil ulangan, peneliti juga sekaligus melakukan pengamatan awal pada kegiatan proses belajar peserta didik. Dalam pengamatan itu, peneliti telah memperoleh gambaran seperti berikut : a. peserta didik kurang aktif saat kegiatan pembelajaran, mungkin karena kegiatan belajar mengajar yang masih terpusat kepada pendidik dan masih mengandalkan pendidik secara penuh, peserta didik juga kadang sedikit kurang percaya diri, b. Pendidik kurang adanya melakukan variasi seperti, alat/media, strategi dan metode dalam proses pembelajaran, seperti menggunakan alat, media atau strategi yang dapat menarik peserta didik untuk belajar, c. Pendidik jarang mengadakan tatap maya, proses pembelajaran lebih sering dilakukan melalui whatsapp group (WAG) sekolah, d. Pendidik juga jarang mengulas kembali materi yang telah dipelajari maupun menerangkan tugas yang diberikan kepada peserta didik, e. Ketika proses pembelajaran dengan menggunakan zoom beberapa peserta didik terkadang kurang fokus, atau dapat teralihkan oleh keadaan sekitar seperti oleh suara-suara berisik yang 
ada di sekitar. Oleh sebab itu kelas kurang kondusif dan peserta didik masih harus diingatkan untuk mematikan microphone.

\section{Hasil Data Siklus I}

Pada hasil tes evaluasi di siklus I telah mengalami peningkatan dibandingkan dengan nilai pra siklus. Pada siklus I ini terdapat 20 siswa yang telah memperoleh predikat tuntas dan terdapat 8 siswa lainnya mendapat predikat tidak tuntas. Berdasarkan hasil presentase keberhasilan belajar siswa pada siklus I telah menunjukkan bahwa baru $71 \%$ dari jumlah siswa yang telah berhasil memperoleh nilai diatas kriteria ketuntasan minimal, sedangkan ada 29\% dari jumlah siswa belum berhasil mencapai nilai diatas kriteria ketuntasan minimal. Hal ini menunjukkan bahwa hasil belajar siswa yang telah diperoleh dari nilai tes evaluasi belum dapat memenuhi target yang sebelumnya telah ditentukan dalam penelitian tindakan pada pembelajaran IPA materi sumber energi tema kayanya negeriku dengan menggunakan media mind mapping digital. Hasil dari tes saat pelaksanaan di kelas yaitu 20 siswa mendapatkan nilai dengan kriteria tuntas atau dengan presentase $71 \%$, sedangkan 8 siswa tidak mendapatkan nilai dengan kriteria tuntas atau dengan presentase $29 \%$. Berikut adalah tabel hasil ketuntasan belajar siklus I:

Tabel 2 Ketuntasan Belajar Siklus I

\begin{tabular}{|c|c|c|}
\hline Nilai & Banyaknya Siswa & Keterangan \\
\hline$>72$ & 20 siswa & Tuntas \\
\hline$<72$ & 8 siswa & Tidak Tuntas \\
\hline
\end{tabular}

Nilai rata-rata hasil ulangan (pra siklus)

$=2253: 28$ siswa $=80.46$. Hasil ketuntasan

belajar pada pelaksanaan tes siklus I:

$\frac{20}{28} \times 100 \%=71 \%$ dan $\frac{8}{28} \times 100 \%=29 \%$

\section{Hasil Data Siklus II}

Pada hasil tes evaluasi di siklus II telah mengalami peningkatan yang cukup signifikan, dibandingkan dengan siklus I sebelumnya. Jika sebelumnya pada siklus I mendapatkan $71 \%$ (20 siswa) dari jumlah siswa yang telah berhasil memperoleh nilai diatas KKM, maka pada siklus II ini telah didapatkan hasil mencapai 100\% (28 siswa) dari jumlah keseluruhan siswa yang telah berhasil mendapatkan nilai diatas kriteria ketuntasan minimal (KKM). Hal ini dapat diartikan bahwa hasil belajar siswa yang ada pada siklus II telah mencapai target keberhasilan penelitian. Tentunya ini berdasarkan hasil belajar yang telah dicapai siswa, maka dapat disimpulkan penggunaan media mind mapping digital dapat meningkatkan hasil belajar pada siswa kelas IV mata pelajaran IPA materi sumber energi tema kayanya negeriku.

Hasil dari tes saat pelaksanaan di kelas yaitu 20 siswa mendapatkan nilai dengan kriteria tuntas atau dengan presentase $71 \%$, sedangkan 8 siswa tidak mendapatkan nilai dengan kriteria tuntas atau dengan presentase 29\%. Berikut adalah tabel hasil ketuntasan belajar siklus II:

\section{Tabel 3 Ketuntasan Belajar Siklus II}

\begin{tabular}{|c|c|c|}
\hline Nilai & Banyaknya Siswa & Keterangan \\
\hline$>72$ & 28 siswa & Tuntas \\
\hline$<72$ & 0 siswa & Tidak Tuntas \\
\hline
\end{tabular}

Nilai rata-rata hasil ulangan (pra siklus)

$=2465: 28$ siswa $=88.04$ hasil ketuntasan belajar pada pelaksanaan tes siklus II: 


$$
\begin{aligned}
\frac{28}{28} \times 100 \% & =100 \% \text { dan } \frac{0}{28} x \\
100 \% & =0 \%
\end{aligned}
$$

\section{B. PEMBAHASAN PENELITIAN}

\section{Paparan Data Pra Siklus}

Penelitian ini dilakukan dalam 2 siklus untuk meningkatkan hasil belajar IPA materi sumber energi tema kayanya negeriku dengan menggunakan media mind mapping digital. Pada Data awal yang akan digunakan peneliti untuk mengetahui kemampuan awal siswa kelas IVB SDN Pengadegan 07 Jakarta Selatan yang mengacu pada nilai hasil ulangan harian mata pelajaran IPA.

Hasil nilai ulangan harian (pra siklus) maka dapat diketahui bahwa kemampuan belajar siswa pada mata pelajaran IPA materi sumber energi tema kayanya negeriku masih terbilang rendah. Telah diperoleh pada presentase ketuntasan hasil belajar klasikalnya hanya mencapai 50\%, karena hanya 14 siswa yang telah memperoleh kriteria nilai tuntas sedangkan 14 siswa lainnya memperoleh nilai dibawah kriteria ketuntasan minimal (KKM). Hasil nilai rata-rata klasikal yang telah dicapai siswa adalah sebesar 76,1. Hal tersebut menunjukkan bahwa hasil belajar siswa pada mata pelajaran IPA materi sumber energi tema kayanya negeriku masih belum mencapai nilai yang memuaskan.

Kegiatan siklus I ini telah dilaksanakan dalam 3 (tiga) kali pertemuan. Pada pertemuan ke-1 yang dilaksanakan dihari Senin, 14 Juni 2021. Pertemuan yang ke-2 telah dilaksanakan pada hari Rabu, 16 Juni 2021. Pertemuan yang ke-3 telah dilaksanakan pada hari Jumat, 18
Juni 2021. Alokasi waktu yang dilaksanakan pada setiap pertemuan adalah $2 \times 35$ menit pembelajaran. Disetiap akhir pertemuan siklus I peneliti akan mengadakan tes akhir (posttest) yang ditunjukkan untuk siswa. Tes akhir (posttest) tersebut digunakan yang bertujuan untuk mengukur sejauh mana pengetahuan serta pemahaman siswa terhadap materi yang telah dipelajari. Pelaksanaan tindakan kelas pada siklus I ini terbagi dalam empat tahap, yaitu perencanaan, pelaksanaan tindakan, observasi, dan juga refleksi.

\section{Paparan Data Siklus I}

Hasil penelitian dapat dijabarkan oleh peneliti untuk mengambil kesimpulan dari hasil seluruh pertemuan yang telah dilakukan dalam tiga kali pertemuan selama siklus I. Jumlah skor yang telah diperoleh selama tiga kali pertemuan adalah : $\frac{85+85+85}{3}=\frac{255}{3}=85$. Skor maksimal adalah yaitu 100. Hal tersebut menunjukkan bahwa keberhasilan aktivitas pembelajaran yang dibawakan oleh peneliti yang melakukan tindakan langsung sebagai guru berada pada kategori baik.

\section{Tabel 4 Hasil Lembar Observasi Guru pada} Siklus I

\begin{tabular}{|c|c|c|c|c|}
\hline \multirow{2}{*}{ No. } & \multirow{2}{*}{ Aspek yang diamati } & \multicolumn{3}{|c|}{ Penilaian } \\
\cline { 3 - 5 } & Kegiatan Pembelajaran & 85 & 85 & 85 \\
\hline 1 & Jumlah & \multicolumn{3}{|c}{255} \\
\hline
\end{tabular}

$$
\frac{85+85+85}{3}=\frac{255}{3}=85
$$

Keterangan :

*Skor Maksimal pada lembar observasi guru adalah yaitu 100, 
dengan maksimal skor adalah yaitu 4 dalam setiap bobot penilaian

*Rentang Nilai :

Nilai $76-100=$ Baik

Nilai $51-75=$ Sedang

Nilai $51-75=$ Sedang

Nilai $25-50=$ Kurang (Sudjana, 2017)

Setelah melaksanakan kegiatan pembelajaran melalui penggunaan media mind mapping digital, kemudian pada setiap akhir pertemuan peneliti memberikan sebuah tes akhir (posttest) kepada siswa, untuk mengukur kemampuan siswa dalam memahami materi yang telah diberikan dan disampaikan oleh guru. Masing-masing tes akhir (posttest) berisikan 10 butir soal yang berbentuk pilihan ganda. Dalam penelitian tes akhir (posttest) ini, jawaban benar pada setiap soal dikalikan dengan 10. Hingga skor maksimal yang dapat dicapai oleh siswa pada setiap tes adalah yaitu 100. Hasil dari tes saat pelaksanaan di kelas yaitu 20 siswa mendapatkan nilai dengan kriteria tuntas atau dengan presentase $71 \%$, sedangkan 8 siswa tidak mendapatkan nilai dengan kriteria tuntas atau dengan presentase $29 \%$.

\section{Paparan Data Siklus II}

Berdasarkan hasil dari tindakan serta pengamatan yang telah dilaksanakan pada siklus I, yang menunjukkan hasil bahwa tingkat kemampuan pemahaman siswa dan juga hasil belajar siswa terhadap materi sumber energi sudah lumayan optimal namun belum mencapai hasil yang sangat optimal. Maka untuk itu, peneliti bersama guru akan kembali memberikan tindakan pembelajaran pada materi sumber energi dengan penggunaan media mind mapping digital untuk meningkatkan hasil belajar siswa kelas IVB SDN Pengadegan 07.

Pada siklus II ini, pelaksanaan tindakan akan dilakukan sebanyak 3 kali pertemuan. Pertemuan pertama akan dilaksanakan pada hari Senin, 21 Juni 2021. Kemudian pertemuan kedua akan dilaksanakan pada hari Rabu, 23 Juni 2021. Dan pertemuan ketiga akan dilaksanakan pada hari Kamis, 24 Juni 2021. Pelaksanaan tindakan yang ada pada siklus II ini terbagi atas empat tahap, yaitu perencanaan, pelaksanaan tindakan, observasi, serta refleksi.

Hasil penelitian yang telah diperoleh dari aktivitas belajar guru adalah mencapai sebesar 90. Sedangkan skor maksimal yaitu adalah 100. Perhitungan rata-rata tersebut dinilai dengan menggunakan rumus sebagai berikut : $\frac{90+90+90}{3}=\frac{270}{3}=90$. Maka, aktivitas guru dalam pembelajaran yang telah dilaksanakan pada siklus II dapat dikategorikan baik.

Tabel 5 Hasil Lembar Observasi Guru Pada Siklus II

\begin{tabular}{|c|c|c|c|c|}
\hline \multirow{2}{*}{ No. } & Aspek yang diamati & \multicolumn{3}{|c|}{ Penilaian } \\
\cline { 3 - 5 } & Kegiatan & 90 & 90 & P3 \\
\hline 1 & Pembelajaran & \multicolumn{3}{|c|}{255} \\
\hline
\end{tabular}

$$
\frac{85+85+85}{3}=\frac{270}{3}=90
$$

Keterangan :

*Skor Maksimal pada lembar observasi guru adalah yaitu $\mathbf{1 0 0}$,

dengan maksimal skor adalah yaitu 4 dalam setiap bobot penilaian

*Rentang Nilai : 
Nilai $76-100=$ Baik

Nilai $51-75=$ Sedang

Nilai $51-75=$ Sedang

Nilai $25-50=$ Kurang (Sudjana, 2017)

Melihat dari permasalahan yang sebelumnya ada pada proses belajar yang dilaksanakan pada siklus I sudah mulai dapat diatasi oleh peneliti pada siklus II ini. Seperti bersama-sama membahas tugas yang diberikan dan memberi kesempatan kepada siswa untuk bertanya tentang tugas yang diberikan, siswa memahami tugas dan materi yang telah diberikan. Juga kelas daring lebih kondusif dari sebelumnya, siswa lebih percaya diri dan menjadi aktif saat diskusi bersama guru saat proses pembelajaran. Saat diselingi ice breaking ditengah-tengah proses pembelajaran siswa terlihat dapat lebih fokus dalam melanjutkan pembelajaran. Sehingga hasil belajar siswa mengalami peningkatan, ini berdasarkan pada tes akhir yang telah diberikan disetiap akhir pertemuan. Hasil dari tes saat pelaksanaan di kelas yaitu 20 siswa mendapatkan nilai dengan kriteria tuntas atau dengan presentase $71 \%$, sedangkan 8 siswa tidak mendapatkan nilai dengan kriteria tuntas atau dengan presentase $29 \%$.

\section{Peningkatan Hasil Belajar IPA Materi Sumber Energi}

Hasil belajar siswa kelas IVB SDN Pengadegan 07 Jakarta Selatan setelah memperoleh pengalaman belajar dengan menggunakan media mind mapping digital telah mengalami peningkatan mulai dari pra siklus, siklus I dan juga siklus II. Sebagian besar siswa telah dapat mencapai ketuntasan minimal pada siklus II, meskipun ada dua orang siswa yang belum mencapai ketuntasan minimal (KKM) yang telah ditentukan.

Tabel 6 Rekapitulasi Hasil Penelitian

\begin{tabular}{|c|l|c|c|c|}
\hline No & Kriteria & $\begin{array}{c}\text { Pra } \\
\text { Siklus }\end{array}$ & $\begin{array}{c}\text { Siklus } \\
\text { I }\end{array}$ & $\begin{array}{c}\text { Siklus } \\
\text { II }\end{array}$ \\
\hline 1. & $\begin{array}{l}\text { Rata-rata } \\
\text { kelas }\end{array}$ & 76,1 & 80,4 & 88 \\
\hline 2. & $\begin{array}{l}\text { Siswa } \\
\text { Tuntas } \\
\text { Belajar }\end{array}$ & $50 \%$ & $71 \%$ & $100 \%$ \\
\hline 3. & $\begin{array}{l}\text { Siswa Tidak } \\
\text { Tuntas } \\
\text { Belajar }\end{array}$ & $50 \%$ & $29 \%$ & $0 \%$ \\
\hline 4. & $\begin{array}{l}\text { Hasil } \\
\text { Observasi } \\
\text { Aktivitas } \\
\text { Guru }\end{array}$ & - & $85 \%$ & $90 \%$ \\
\hline 5. & $\begin{array}{l}\text { Hasil } \\
\text { Observasi } \\
\text { Aktivitas } \\
\text { Siswa }\end{array}$ & - & $85 \%$ & $90 \%$ \\
\hline
\end{tabular}

Nilai ulangan siswa kelas IVB SDN Pengadegan 07 Jakarta Selatan pada mata pelajaran IPA, berdasarkan pada hasil tes pra siklus, yang menunjukkan bahwa siswa yang mendapat nilai $<72$ adalah sebanyak 14 siswa $(50 \%)$ dan $\geq 72$ sebanyak 14 siswa $(50 \%)$ dengan nilai rata-rata kelas adalah 76,1. Kemudian pada tes yang telah dilakukan di siklus I, nilai rata-rata adalah 80,4 dengan jumlah siswa yang tuntas $\geq 72$ sebanyak 20 orang $(71 \%)$ dan siswa yang tidak tuntas $<72$ adalah sebanyak 8 orang (29\%). Sedangkan pada siklus II siswa yang telah memperoleh nilai $\geq 72$ adalah 28 orang $(100 \%)$ dan yang telah memperoleh nilai $<72$ adalah sebanyak 0 orang $(0 \%)$ dengan nilai rata-rata kelas sebesar 88. Pada kriteria yang telah ditentukan yaitu lebih dari $85 \%$.

Menurut Wahyu Bagja Sulfemi yang berjudul "Model Pembelajaran Kooperatif 
Mind Mapping Berbantu Audio Visual Dalam Meningkatkan Minat, Motivasi Dan Hasil Belajar IPS". Penelitian memiliki hasil yang baik dalam penggunaan model kooperatif (Cooperative Learning) tipe Mind Mapping dapat meningkatkan minat, motivasi serta hasil belajar peserta didik secara signifikan. Penelitian menurut Elma Silvia dengan judul penelitian "Peningkatan Hasil Belajar IPA melalui Model Pembelajaran Mind Mapping di SDN Ciater 03 Tanggerang Selatan”. Penelitian ini menghasilkan telah terjadinya peningkatan pada hasil belajar IPA yang cukup baik pada peserta didik kelas IV. Berdasarkan hasil analisis data penelitian tindakan kelas yang sudah dilakukan oleh peneliti pada peserta didik kelas IV SDN Ciater 03 Tanggerang Selatan bahwa model Mind Mapping dapat meningkatkan hasil belajar peserta didik. Hasil akhir penelitian tindakan ini memiliki nilai pada siklus I dengan nilai 70.30, siklus II dengan nilai 77.91 dan siklus III dengan nilai 80.90 dari hasil tersebut telah mengalami peningkatan pada nilai siswa dan dikatakan berhasil.

Berdasarkan hasil siklus I dan siklus II, ketuntasan hasil belajar mengalami peningkatan, hal ini bisa dilihat dari nilai siswa, dan pemahaman siswa dalam mempelajari materi dengan menggunakan media mind mapping serta siswa bisa menjadi aktif saat kegiatan pembelajaran. Kegiatan pembelajaran yang efektif yaitu siswa aktif untuk memahami materi yang diberikan guru (Kristianingsih et al., 2017).

Hasil pada penelitian ini bisa diakhiri dan sudah dianggap berhasil dalam pelaksanaan tindakan karena telah mencapai tujuan yang ditentukan dan juga diharapkan. Penerapan penggunaan media mind mapping digital ternyata mampu meningkatkan hasil belajar siswa pada mata pelajaran IPA materi sumber energi tema kayanya negeriku di kelas IVB SDN Pengadegan 07 Jakarta Selatan.

\section{SIMPULAN}

Media mind mapping digital mampu meningkatkan hasil belajar peserta didik di kelas IVB SDN Pengadegan 07 pagi Jakarta Selatan pada mata pelajaran IPA khususnya materi sumber energi. Hasil siklus I dan siklus II pada pembelajaran IPA secara daring sebelum digunakan media mind mapping digital diperoleh nilai pra siklus hasil belajar siswa secara klasikal dengan rata-rata sebesar 76,1 dan persentase ketuntasan klasikalnya yaitu 50\%. Siklus I mengalami peningkatan hasil belajar yaitu nilai rata-rata klasikalnya menjadi 80,4 dengan persentase ketuntasan klasikalnya $71 \%$, serta siklus II mendapatkan peningkatan yang siginfikan dengan memperoleh nilai rata-rata menjadi 88 dengan persentase ketuntasan klasikal sebesae 100\%.

\section{DAFTAR RUJUKAN}

Kristianingsih, D. D., Sukiswo, S. E., \& Khanafiyah, S. (2017). Peningkatan Hasil Belajar Siswa Melalui Model Pembelajaran Inkuiri Dengan Metode Pictorial Riddle Pada Pokok Bahasan Alat- Alat Optik Di Smp. Jurnal Pendidikan Fisika Indonesia, 6(1), 10-13. https://doi.org/10.15294/jpfi.v6i1.1095

Novioleta, R., Wedyawati, N., Kurniati, A., Novioleta, R., Wedyawati, N., \& Kurniati, A. (2020). Jurnal Pendidikan 
Dasar Perkhasa Model Mind Mapping pada Pembelajaran Tematik. 6(April), 41-54.

Rizkyani, M., \& Amelia, W. (2020). Peningkatan Hasil Belajar Matematika Materi Satuan Panjang Melalui Media Flash Card pada Siswa Kelas IIB SDN Kayuringin Jaya VI Bekasi. 141-148.

Sudjana, D. N. (2017). Penilaian Hasil Proses Belajar Mengajar.Pdf. PT Remaja Rosdakarya.

Sutanto, W. (2013). 1 st Mind Map untuk Siswa, Guru dan Orangtua..pdf. PT Elex Media Komputindo.

Variani, \& Agung. (2020). Model Pembelajaran Savi Berbantuan Media Mind Mapping Meningkatkan Hasil Belajar IPA Siswa Kelas V. Jurnal Pedagogi Dan Pembelajaran, 3(2), 269. https://doi.org/10.23887/jp2.v3i2.26615

Wayan, D. I., \& Ketut, S. I. (2020). Penerapan Metode Pembelajaran Mind Mapping Berbantuan Media Whatsapp Untuk. 3(2). https://stahnmpukuturan.ac.id/jurnal/inde x.php/bhuwana/article/view/956

Widiana, I. W. (2016). Pengembangan Asesmen Proyek Dalam Pembelajaran Ipa Di Sekolah Dasar. JPI (Jurnal Pendidikan Indonesia), $\quad 5(2), \quad 147$. https://doi.org/10.23887/jpiundiksha.v5i2.8154

Yuliani, S. H., Prasetyo, T., \& Mawardini, A. (2020). Pengaruh Metode Mind Mapping Pada Daur Hidup Di Kelas Empat. SITTAH: Journal of Primary Education, l(1), $31-44$. https://doi.org/10.30762/sittah.v1i1.2071

Yuliani, S. H., Teguh Prasetyo, \& Mawardini, A. (2020). Pengaruh Metode Mind Mapping Pada Daur Hidup Di Kelas Empat. Sittah: Journal of Primary Education, $\quad 1(1), \quad 31-44$. https://doi.org/10.30762/sittah.v1i1.2071 